\title{
Stereotactic radiosurgery alone for small cell lung cancer: a neurocognitive benefit?
}

\author{
Eric Ojerholm", Michelle Alonso-Basanta and Charles B Simone II
}

\begin{abstract}
Yomo and Hayashi reported results of stereotactic radiosurgery alone for brain metastases from small cell lung cancer. This strategy aims to avoid the neurocognitive effects of whole-brain radiation therapy. However, radiosurgery alone increases the risk of distant intracranial relapse, which can independently worsen cognition. This concern is heightened in histologies like small cell with high predilection for intracranial spread. The majority of study patients developed new brain disease, suggesting radiosurgery alone may not be an optimal strategy for preserving neurocognitive function in this population. We suggest whole-brain radiation therapy should remain the standard of care for small cell lung cancer.
\end{abstract}

Keywords: Small cell lung cancer, Stereotactic radiosurgery, Whole-brain radiation therapy, Neurocognitive, Prophylactic cranial irradiation

\section{Correspondence/Findings}

\section{Letter to the Editor:}

Yomo and Hayashi recently reported in Radiation Oncology their experience with upfront stereotactic radiosurgery (SRS) for brain metastases from small cell lung cancer (SCLC) [1]. The authors should be commended for this novel investigation. We agree that SRS might play a role in SCLC, particularly for treating a limited number of brain metastases after prior prophylactic cranial irradiation or prior whole-brain radiation therapy (WBRT). However, we echo the authors' call for caution in adopting SRS alone as the initial approach for intracranial disease.

The strategy of upfront SRS is gaining increasing prominence [2], spurred by the excellent local control achieved with radiosurgery and by concerns about the side effects of WBRT. These concerns are bolstered by studies showing declines in neurocognition and quality of life in patients receiving WBRT [3-5]. On the other hand, increased intracranial tumor burden often drives cognitive dysfunction [6,7], and a recognized downside of SRS alone is high rates of distant brain relapse. This concern is heightened in SCLC, a biologically aggressive tumor which disseminates to the central nervous system

\footnotetext{
* Correspondence: eric.ojerholm@uphs.upenn.edu

Department of Radiation Oncology, University of Pennsylvania, 3400 Civic

Center Boulevard, PCAM-2 West, Philadelphia, PA 19104, USA
}

in approximately two-thirds of patients during the course of their disease [8]. Yomo and Hayashi report that 20 of 41 patients (49\%) developed new brain metastases after initial SRS, and because follow-up imaging was available in only 34 cases, this rate could be interpreted as 20 of 34 (59\%). The overall outcomes from this study suggest that radiosurgery may be a reasonable modality in wellselected patients with SCLC. However, it is also possible that in populations with high rates of intracranial relapse, an SRS approach might actually hinder - rather than help - cognitive function.

Which is more important for preserving neurocognition: limiting the volume of irradiated brain or maximizing intracranial tumor control? The answer is uncertain, and ongoing studies aim to resolve this question (e.g. NAGKC 12-01 testing WBRT versus SRS alone for five or more brain metastases and NCCTG N107C testing WBRT versus SRS following surgical resection of a brain metastasis). Should these trials favor SRS, we anticipate increased enthusiasm for radiosurgery in all tumor histologies - including SCLC - and Yomo and Hayashi's study will be an important initial report in this population. In the meantime, however, we suggest that WBRT remain the standard of care for patients with brain metastases from SCLC. 


\section{Abbreviations}

SRS: Stereotactic radiosurgery; SCLC: Small-cell lung cancer; WBRT: Whole-brain radiation therapy.

\section{Competing interests}

The authors declare that they have no competing interests.

\section{Authors' contributions}

$E O, M A B$, and $C B S$ 2nd conceived of, drafted, and critically revised the letter All authors read and approved the final version.

\section{Author information}

MAB is Chief of the Central Nervous System Service and CBS 2nd is Chief of the Thoracic Service in the Department of Radiation Oncology.

Received: 29 August 2014 Accepted: 14 September 2014

Published: 30 September 2014

\section{References}

1. Yomo S, Hayashi M: Upfront stereotactic radiosurgery in patients with brain metastases from small cell lung cancer. Radiat Oncol 2014, 9:152.

2. Yamamoto M, Serizawa T, Shuto T, Akabane A, Higuchi Y, Kawagishi J, Yamanaka K, Sato Y, Jokura H, Yomo S, Nagano O, Kenai H, Moriki A, Suzuki S, Kida Y, Iwai Y, Hayashi M, Onishi H, Gondo M, Sato M, Akimitsu T, Kubo K, Kikuchi Y, Shibasaki T, Goto T, Takanashi M, Mori Y, Takakura K, Saeki N, Kunieda E et al: Stereotactic radiosurgery for patients with multiple brain metastases (JLGK0901): a multi-institutional prospective observational study. Lancet Oncol 2014, 15(4):387-395.

3. Gondi V, Paulus R, Bruner DW, Meyers CA, Gore EM, Wolfson A, Werner-Wasik $M$, Sun AY, Choy H, Movsas B: Decline in tested and self-reported cognitive functioning after prophylactic cranial irradiation for lung cancer: pooled secondary analysis of Radiation Therapy Oncology Group randomized trials 0212 and 0214. Int J Radiat Oncol Biol Phys 2013, 86(4):656-664.

4. Chang EL, Wefel JS, Hess KR, Allen PK, Lang FF, Kornguth DG, Arbuckle RB, Swint JM, Shiu AS, Maor MH, Meyers CA: Neurocognition in patients with brain metastases treated with radiosurgery or radiosurgery plus whole-brain irradiation: a randomised controlled trial. Lancet Oncol 2009, 10(11):1037-1044.

5. Soffietti R, Kocher M, Abacioglu UM, Villa S, Fauchon F, Baumert BG, Fariselli L, Tzuk-Shina T, Kortmann RD, Carrie C, Ben Hassel M, Kouri M, Valeinis E, van den Berge D, Mueller RP, Tridello G, Collette L, Bottomley A: A European Organisation for Research and Treatment of Cancer phase III trial of adjuvant whole-brain radiotherapy versus observation in patients with one to three brain metastases from solid tumors after surgical resection or radiosurgery: quality-of-life results. J Clin Oncol 2013, 31(1):65-72.

6. Li J, Bentzen SM, Renschler M, Mehta MP: Regression after whole-brain radiation therapy for brain metastases correlates with survival and improved neurocognitive function. J Clin Oncol 2007, 25(10):1260-1266.

7. Regine WF, Scott C, Murray K, Curran W: Neurocognitive outcome in brain metastases patients treated with accelerated-fractionation vs. accelerated-hyperfractionated radiotherapy: an analysis from Radiation Therapy Oncology Group Study 91-04. Int J Radiat Oncol Biol Phys 2001, 51(3):711-717.

8. Seute T, Leffers $P$, Ten Velde GP, Twijnstra A: Neurologic disorders in 432 consecutive patients with small cell lung carcinoma. Cancer 2004, 100(4):801-806.

Cite this article as: Ojerholm et al: Stereotactic radiosurgery alone for small cell lung cancer: a neurocognitive benefit? Radiation Oncology 2014 9:218.

\section{Submit your next manuscript to BioMed Central and take full advantage of:}

- Convenient online submission

- Thorough peer review

- No space constraints or color figure charges

- Immediate publication on acceptance

- Inclusion in PubMed, CAS, Scopus and Google Scholar

- Research which is freely available for redistribution 